\title{
The Professionalization of Baccalaureate-Level Social Work
}

\author{
Bradford W. Sheafor
}

\begin{abstract}
We are occasionally privileged to observe an important event in the history of some aspect of life, but one is rarely an eyewitness to the birth of a profession - or even a specific division of a profession. Nevertheless, along with others, I had the privilege of participating in a series of events over several years that, with hindsight, I realize made me a witness to the birth of baccalaureate social work. This article reflects the perspective of one person engaged in these events and may differ from the observations of other participants. Yet, it represents my best recollection of events that began nearly fifty years ago.
\end{abstract}

Keywords: Social work education, baccalaureate social work, Association of Baccalaureate Social Work Program Directors, social work as a profession

\section{The Emergence of a Profession: Social Work}

Professions emerge over time and efforts to pin down the date an occupation became a profession depends on the pace of the development of the occupation and the definition one uses to determine professional status. For example, in my view the National Association of Social Workers (NASW) jumped the gun in 1998 when, based on the date of the initiation of the first training program at the New York School of Philanthropy, NASW celebrated the $100^{\text {th }}$ birthday of social work. In reality, in 1898 we were far from being a profession. The title, social work, was not coined by Jeffery Brackett (Sheafor \& Horejsi, 2012, p. 3) until the early 1900s and it was not until 1915 that Abraham Flexner constructed generally accepted criteria for concluding that an occupation has indeed become a profession (Flexner, 1916). At that time Flexner concluded that social work did not meet the expectations for being recognized as a profession.

I would argue that somewhere in the 1930s would be the first time a defensible argument could be made for having achieved professional status. By that time social work had in place an accreditation process (at the MSW level), required that academic preparation for social workers must be in institutions of higher education, and had created a stable national membership organization (the American Association of Social Workers, a predecessor the National Association of Social Workers). Then, like a cell dividing into separate but related structures, social work moved in the 1960s and 1970s to carve out a place for a professionally prepared baccalaureate social worker.

\section{Personal Background: Establishing My Vantage Point}

In the late 1950s I stumbled into social work thanks to opportunities derived from leadership roles I played in a few human service-related organizations while in high school and college - and the influence of several mentors who were social workers.

Bradford W. Sheafor, Ph.D., is a Professor Emeritus of Social Work at Colorado State University in Fort Collins, CO.

Copyright (C) 2014 Advances in Social Work Vol. 15 No. 1 (Spring 2014), 196-206 
These events shaped my recognition of the need for baccalaureate-level social work education and my appreciation of the "generalist" model of social work.

As an undergraduate student making the decision to enter social work, I looked at what courses I would need in order to complete a social work major. At that time undergraduate programs were restricted from offering much substance - and certainly not practice courses and sound field experiences. Further, there was not recognition of the degree in the human services employment market or upon entering a master's program. I decided to complete my default major (Business Administration) and apply to the MSW degree program at the University of Kansas. I wonder how many undergraduates were similarly diverted from social work and then never returned. Initially being most interested in community and organizational levels of practice, I was out-of-step with the dominant casework/psychiatric social work orientation of that era, but was forced into a "casework" curriculum with only introduction to group work, administration, and community organization. Fortunately, my macro interests were supported by a few faculty members and through independent study courses and I was able to gain some depth in community practice. The combination of direct and indirect practice prepared me to embrace the generalist model later in my career.

Upon completion of my MSW in 1961, I fell into a job for which I was only marginally prepared: Executive Director of a community health and welfare planning council in Topeka, Kansas, my hometown, with an impressive $\$ 450$ per month salary. Thus began my career as a professional social worker. We had some surprising successes in the community planning council and three years later the head of the School of Social Welfare at the University of Kansas offered me a two-year lectureship to create a bachelor's-level social work program - one that would have substance and meet the emerging national standards. I hadn't even considered becoming an educator, but with no application needed, no interview to suffer through (Who had even heard of affirmative action?), and a nine-month salary that exceed my twelve-month salary with the planning council, I jumped at the job. It was from this background that I had the rare opportunity to observe and participate in the development of a new level of the social work profession.

\section{First Steps in BSW Emergence}

\section{The War on Poverty}

In an effort to implement the War on Poverty programs in the mid-1960s, the U.S. Department of Health, Education, and Welfare (HEW) recognized that the MSW programs would be unable to graduate enough social workers to meet the expected demand and, further, a large percentage of the psychiatric social workers they graduated were not interested in staffing the poverty programs. Yet, HEW insisted that persons with preparation in applying knowledge and skills in the delivery of human services were needed to serve this vulnerable population - more than was found in the preparation of psychology or sociology undergraduate majors. Therefore, HEW created incentives for universities and colleges to create undergraduate social work education programs, but also realized that there must be recognition of that degree in the employment market if 
the effort was to succeed. Thus NASW was prevailed upon to designate graduates from bachelors-level social work education programs as first-level professional social workers. Immediate opposition was expressed by many masters-level programs that had previously flat-out rejected Herb Bisno's insightful volume on a blueprint for the future of baccalaureate social work education, Volume 2 in the Council on Social Work Education's (CSWE) multi-volume curriculum study chaired by Werner Boehm (Bisno, 1959).

\section{The NASW Referendum}

In 1969 NASW put forth the referendum to recognize as professional the graduates of accredited baccalaureate programs (BSWs). In addition to having responsibility for building the BSW program at the University of Kansas (my position magically turned into a tenure-track position), I served as chair of the Topeka (Kansas) NASW chapter and president of the Kansas Council of NASW chapters. Thus I was deeply embroiled in the controversy surrounding this contentious resolution. As I recall, five major themes dominated the discussion.

Theme \#1: The demand for practitioners with basic social work knowledge and skill exceeds the supply of MSW social workers and if social work fails to change, another discipline will take this over as a baccalaureate-level specialty $>$ VERSUS < Social work has worked 50 years to achieve professional recognition and now approving a lower educational level as professional is a step backward.

Theme \#2: Many social work activities do not require the depth of MSW preparation> VERSUS <Professionalizing the BSW with lesser knowledge and skill than the MSW will diminish the reputation of the profession and reduce the ability of MSWs to function as peers with other helping professions.

Theme \#3: BSW programs will attract qualified traditional and non-traditional age students who otherwise will drift into other disciplines $>$ VERSUS $<$ The immaturity of undergraduate students will prevent them from understanding the complexity of social problems and reduce respect for the social work profession.

Theme \#4: By creating social work jobs addressing client needs requiring only bachelor's-level preparation the agencies can be more efficient and stretch limited resources to serve more clients $>$ VERSUS $<$ Agencies will substitute BSWs for MSWs because they command less salary and the distinction between the two levels will disappear.

Theme \#5: Beyond obtaining a general education, it doesn't make sense for undergraduate students intending to become social workers to fill credit hour requirements with courses from other disciplines> VERSUS $<$ Content will be commandeered from the MSW level and there will be problems in distinguishing between the levels - and even with master's 
programs completely redesigning their curricula there will inevitably be overlap.

To the surprise of many (including me), the referendum passed and the task of operationalizing this new professional level required the formulation of standards for the education of undergraduate students that would lead to accreditation of the programs that demonstrate inclusion of necessary content and provide high quality instruction.

\section{CSWE Develops a Curriculum Policy Statement and Accreditation Standards}

Responsibility fell to the Council on Social Work Education (CSWE) to generate a set of accreditation standards, coupled with a curriculum policy statement that recognized the two levels of social work practice. During this time I had the opportunity to serve on CSWE's Educational Planning Commission where an effort was made to identify content that would be purely BSW (there was not much), content that would overlap the two programs (about the equivalent of a year of MSW education), and specialized content that belonged at the master's level only.

In regard to accreditation, the first step was a set of "approval" standards that did not yet meet the more substantive requirements necessary for recognition as "accreditation" by the interdisciplinary body granting accreditation authority for the professions, then the Council on Post-Secondary Accreditation (COPA). The approval standards largely addressed structural requirements for such things as financial support from the schools, having social work faculty members prepared to teach social work content (the sociologists and psychologists thought they could teach this material just as well), and some degree of control over curriculum. Application of these standards reduced the number of baccalaureate social work education programs previously "listed" by CSWE from 207 to 158 "approved" programs in 1974 (CSWE, 1973, 1974).

Full accreditation standards, to be implemented in 1974, were approved by CSWE with the expectation that each school would develop its own generalist/specialist concept and build a curriculum to match. Beginning in 1975 I served on CSWE's Commission on Accreditation and saw first-hand the frustration the inexperienced BSW program directors faced in being expected to define generalist and build a defensible curriculum. By the time the cycle was complete, the 158 "approved" schools had declined to 135 "accredited" programs (CSWE Statistics, 1976).

\section{Facing the Realities of a New Practice Level}

The unrest about professionalizing the baccalaureate level of social work was evident in both social work practice and education. For example, the BSW graduates didn't find job descriptions that recognized the degree as a valid job credential. In fact, many agencies were not aware that degree even existed and if they did, they did not appear to appreciate the advantages a social worker with such preparation would bring to a job. NASW seemed paralyzed by the opposition to professionalizing the BSW graduate and did little to promote this new practice level. In return, few bachelor's level social workers joined NASW. Further, the War on Poverty had ended (with little success) and HEW leadership changed, leaving few champions for baccalaureate-level social workers in high 
places. Even in federally mandated programs the BSW was not treated as a valued job credential.

In social work education, too, there was foot-dragging, if not outright hostility about operationalizing the BSW level of education. As a member of the Accreditation Commission it was evident to me that MSW programs received far less scrutiny than BSW programs. In a behind-the-scenes move a few of us who were primarily identified with the BSW level joined a few MSW-identified commissioners in an agreement to apply equal rigor in reviewing both levels. My impression was that indeed this strategy worked and the quality of accreditation review improved at both levels.

Other examples of inequality in the education realm were that the budget, allocation of staff time, focus of journal articles, and lobbying efforts supported by CSWE gave little attention to the BSW level. It was evident that the deans of graduate schools of social work called the shots and their leadership was not favorable to the new practice level, although a number of schools had both BSW and MSW programs. In an attempt to counter the deans' dominant role in social work education, a few of us primarily identified with BSW education concluded that we must form our own organization if this practice level was to be represented and heard when critical decisions were being made. Thus a set of bylaws for the Baccalaureate Program Directors Association (BPD) was drafted and presented to the baccalaureate program director's constituency group during the CSWE Annual Program Meeting in Chicago in 1975. To this day I can picture the large stainless steel refrigerators and counters in the kitchen of the conference hotel--the only affordable (i.e., free) meeting place available to this group that had no resources. I vividly remember Trueheart Titzl ( $1^{\text {st }}$ president of BPD), Kay Dea ( $2^{\text {nd }}$ president of BPD), Betty Baer, Ron Federico, Millie Charles, Will Scott, and many others leaning against the stainless steel kitchen equipment as we discussed and voted approval of the first BPD bylaws. A baccalaureate-level membership organization now existed, although it was entirely made up of educators and did not meaningfully engage BSW practitioners.

\section{Engaging the Constituency}

In 1979 BPD determined that it could further strengthen baccalaureate social work education programs and build commitment to bachelor's level social work by organizing a national conference where people could interact on a face-to-face basis without the distraction of tagging on to a CSWE conference. Ann McLean and I agreed to co-chair a conference focused on "Competency-Based Education." Held at a mountain resort near Estes Park, Colorado (I had become baccalaureate program director at nearby Colorado State University by that time), 52 program directors from all parts of the U.S. attended the three-day event. Off-season rates at Aspen Lodge were very reasonable; faculty from three programs using a competency-based approach presented papers; the Colorado State University media center made a videotape of the presenters being interviewed by other participants, as well as videotaping interviews with representatives from four important pre-BSW projects; scenes from a play, "Jacques Brel Is Alive and Well," were reheated from on-campus performances by my university's theatre department; and an entertainment night brought out music, dance, and other artistic talents of the participants. We even made a little money off donations for soft drinks, beer, and wine that went to the 
paltry BPD treasury. I like to think that the goodwill and free sharing of ideas at this conference set the positive, non-competitive tone that has characterized subsequent BPD conferences and, later, the BPD listserv (i.e., the Baccalaureate Social Work Education List).

Another example of unequal treatment for BSW programs was evident in an annual workshop concerned with leading a school of social work and understanding accreditation requirements sponsored by CSWE for deans, but not baccalaureate program directors. Pressure was applied and CSWE agreed to organize such a workshop for undergraduate programs in 1983. CSWE asked Dr. Titzl to manage local arrangements (which resulted in staying at the infamous convent in Nazareth, Kentucky) and I was asked to lead the program on chairing an academic department. CSWE staff addressed understanding the BSW accreditation requirements. This conference attracted 53 participants. The next year CSWE again invited me to lead a similar workshop with a slightly broader program addressing other issues experienced by BSW programs. We upgraded only slightly from the convent to dormitories on the Colorado State University campus as accommodations for the 77 participants. A party in my backyard generated an informal friendly atmosphere that is often remarked on by the few participants still involved in social work education. In subsequent years CSWE faced serious financial problems and in order to reduce expenditures and reallocate staff time, the sponsorship of these annual meetings was shifted to BPD. Through the leadership of Barbara Shank (now Chair of the CSWE Board of Directors), these meetings began to attract high attendance and became money-making events for BPD - funds that sustained the organization in its early years.

\section{The Drive to Professionalize the Baccalaureate Level of Social Work}

By 1957 Ernest Greenwood (a social worker/sociologist) concluded that social work was now a profession based on five criteria he had synthesized from the sociology of professions (Greenwood, 1957). These criteria were 1) a systematic body of knowledge to underpin the work, 2) authority to determine who is a recognized professional and what the educational preparation should be, 3) sanction from the community to do this work, 4) a code of ethics, and 5) a professional culture where members had a sense of identification with the profession. Three of Greenwood's criteria were not contentious when the effort to build a professional baccalaureate level of social work was undertaken. One was Criterion \#2, as it was clear that NASW had the authority to determine who were the members of the profession and had already voted to include the baccalaureate level social worker. Further, CSWE had the authority to establish any educational requirements. Also, Criterion \#4, the profession's code of ethics was applied equally to all members of the profession and was not an issue for differentiating the practice levels. Finally, the creation of BPD satisfied Criterion \#5 by creating a membership organization representing this level of social work. Although I don't think any of us saw the challenges so clearly at the time, the work that needed to be promoted by BPD was to identify the knowledge needed for this level of practice and to help build high quality social work education programs to deliver that knowledge (Criterion \#1), and to gain sanction from our practice communities (Criterion \#3). 


\section{Defining Appropriate BSW Content and Competencies}

A major effort to further flesh-out the content of BSW-level work was known as the "West Virginia Project," a HEW funded effort located at West Virginia University and led by Betty Baer and Ron Federico. I was privileged to be a participant in that rigorous examination of previous efforts to spell out legitimate "less than master's level" human services positions and then cull out the content appropriate for social work. The project interfaced with the fledgling BPD organization which helped build political support for the results. The first phase of the West Virginia Project focused on content with a sample curriculum model developed that helped program directors gain a perception of what might go into curriculum at this practice level. This model relieved some of the pressure on the schools. The second phase addressed knowledge baccalaureate program directors would need to be savvy enough to build strong programs within their universities and develop the classroom and field instructor skills needed to transmit this content students (Baer \& Federico, 1978, 1979). For example, my chapter was titled "The Social Work Program: Its Place in Higher Education."

Nevertheless, the major sticking point in the implementation of education at the baccalaureate level continued to be identifying the components of generalist practice. Leslie Leighninger helpfully framed the debate (Leighninger, 1980, 1984), but agreement about the content a school should build into its curriculum did not exist. Perhaps a love/hate relationship inherently exists between schools wanting to become accredited and the accrediting bodies. In this case the schools knew that rigorous standards were necessary for accreditation to be considered viable, but how the requirements should be operationalized was at issue. Some schools wanted clear definitive instructions regarding what content and what courses should be required, while others wanted only general guidelines with room to adapt curriculum to regional practice variations. The latter view was adopted and CSWE's Commission on Accreditation became the arbitrator as it made judgments about each school's concept of generalist, its ability to distinguish generalist from specialist content, and its infusion into a curriculum.

Gradually some common elements in generalist (sometimes called generic) social work practice began to shake out. In 1983, Anne Minahan (editor-in-chief for a new edition of the Encyclopedia of Social Work) asked me to write an item for the Encyclopedia on "The Generalist Perspective." My colleague at Colorado State University, Pamela Landon, joined me in this effort and we scoured the developing literature on the topic with our summary of the state of the art at that time appearing in the new edition (Sheafor \& Landon, 1985). In that summary was evidence that there were varying perspectives on generalist and that there was a need to identify where there was consensus and where there were wide variations. Two other colleagues at Colorado State University, Mona Schatz and Lowell Jenkins, were interested in helping to pin-down a generally accepted conception of generalist social work and I joined them in conducting a very elaborate Delphi study involving three rounds of critique and clarification of the concepts that emerged from nearly 50 social work educators. Through this effort we were able to filter out some elements of social work that are generic/foundation material for all social workers, the central components of a generalist perspective and the initial 
competencies needed at the first practice level, and then (somewhat vaguely) the additional competencies needed for practice as an advanced generalist social worker (Schatz, Jenkins, \& Sheafor, 1990). I may be overstating the impact of this research, but I think that perhaps as much as anything it provided a sufficient summary of areas of agreement regarding a conception of generalist that the topic dropped down on the list of problems the BSW programs experienced.

Another problem rested in how to avoid unnecessarily redundant content for BSW graduates who matriculated to MSW programs. Were they to pay tuition just to repeat the content from their baccalaureate program? Should schools be required to avoid redundancy and waive part of the MSW requirement? If so, how much? One year? One term? Should schools require students to test-out of each course? I had nothing to do with this decision, but CSWE concluded that schools should be allowed to implement some form of wavier, called "advanced standing," to address this problem. Only about one-half of the MSW programs initially implemented advanced standing and this became one more point of contention between the leadership of the Council of Deans (now the National Association of Deans and Directors) and the Council on Social Work Education. As President of CSWE in the mid-1980s (the two most trying years of my career), it was clear that advanced standing added to the accumulation of issues and motivated the Council of Deans to encourage its members to withhold their annual dues to CSWE in protest - if not in an effort (as some conspiracy theorists contended) to bankrupt the organization so that a new accrediting body (sans a BSW level) could be created. About one-half of the graduate programs delayed paying their dues and indeed the organization almost collapsed. It is my view the 100 percent dues payment by undergraduate programs and the negotiating skills of the Interim Director of CSWE, Diane Bernard, kept the organization alive - barely.

\section{Promoting the BSW}

Baccalaureate educators and BPD appeared to be effective in promoting the BSW on their campuses, but they were not effective in creating a job market for the graduates. NASW made one valiant stab at upgrading recognition of this practice level in the early 1990s by creating a parallel recognition to the masters-level Academy of Certified Social Workers (ACSW) - the Academy of Certified Baccalaureate Social Workers (ACBSW). Bob Teare and I were commissioned by NASW to extend a task analysis study of MSW social workers we had developed to underpin the ACSW exams, to now address the BSW practice level. Barbara Shank joined us in collecting and analyzing the BSW-level data. Using these data as the blueprint, NASW developed an innovative ACBSW exam in 1991. However, the practice agencies did not buy into this academy, did not recognize the ACBSW as a job credential, and thus students saw little merit in taking the exam and paying the ACBSW fee. The ACBSW subsequently was discontinued by NASW.

\section{Did the Partitioning of Social Work Last?}

Indeed, there were many trials and tribulations as the baccalaureate level of social work became a legitimate professional practice level. So what evidence is there today that this effort succeeded? 
- The CSWE website (http://www.cswe.org, July, 2013) indicated that there were 472 accredited BSW programs and 19 more in candidacy - a significant increase from the 135 programs in 1974.

- The 2012 Annual Survey (also on the CSWE website) reports 52,598 full-time and 7,297 part-time majors. That exceeds the MSW enrollments of 34,484 fulltime and 19,351 part-time students.

- The Annual Survey also indicated that of the new students admitted to MSW programs in 2012, 5,898 were admitted with advanced standing.

- Amanda Scott (BPD staff member) reports that the BPD membership has grown to a substantial number - from 101 charter members to 698 members in 2013.

- Scott also reports that the attendance at the BPD annual meetings has increased exponentially - from 52 at the first meeting in Estes Park, Colorado to 900 at Myrtle Beach, South Carolina in 2013.

- To be a profession, a certain amount of common work must be done by all practitioners, but if there are multiple levels of the profession there also must be some differentiation. In 1995, Bob Teare and I merged comparable data from the NASW sponsored BSW and MSW task analysis studies, yielding 7,000 usable responses which allowed for a comparison of practice activities at the two levels. Chapter 4 in our CSWE published book, Practice-Sensitive Social Work Education (Teare \& Sheafor, 1995), identifies similarities and differences in what social workers do at the two professional levels. There was a clear distinction in that BSWs somewhat exceed MSWs in the empirically derived task clusters of risk assessment, protective services, case planning and maintenance, service connection, tangible service provision, and dispute resolution. The MSWs exceeded the BSWs in group work, individual/family treatment, and staff supervision. In the remaining clusters of practice activity (i.e., interpersonal helping, professional development, staff deployment, staff information exchange, organization maintenance, community delivery system knowledge, program development, research and policy development, and instruction) there was virtually no difference between the two levels.

\section{Conclusion}

In my judgment the above data indicate that social work has become one profession with two somewhat distinct practice/education levels. Looking back on these developments, the opportunity to participate in and contribute to the emergence of a new practice level of a profession was a unique and rewarding experience. The efforts of many colleagues throughout the United States made this possible and, perhaps, the rich interpersonal relationships developed among the BPDers did the most to make the time and effort spent on this personally worthwhile. On a far more important societal level, the outcome of now having nearly 15,000 new and well-prepared baccalaureate level educated professional social workers available each year to serve the most vulnerable U.S. population groups truly has made a difference. 
The single element of Greenwood's criteria for a profession that I believe has not been sufficiently realized is the requirement to gain sanction from our professional communities. To better achieve this important goal, CSWE, BPD, NASW, ASWB and the many human services employers must again undertake carefully planned and articulated strategies to strengthen recognition of these graduates in the employment market. Too often this this rich resource still goes unappreciated.

\section{References}

(Author's Note: In addition to references cited in the body of this article, sources documenting the events associated with these personal observations are also included in the References list.)

Baer, B. L., \& Federico, R. (Eds.). (1978). Educating the baccalaureate social worker (Vol. 1). Cambridge, MA: Ballinger.

Baer. B. L., \& Federico, R. (Eds.). (1979). Educating the baccalaureate social worker (Vol. 2). Cambridge, MA: Ballinger.

Bisno, H. (1959). The place of the undergraduate curriculum in social work education. New York, NY: Council on Social Work Education.

Council on Social Work Education. (1973). Statistics on social work education in the United States: 1973. New York, NY: Author.

Council on Social Work Education. (1974). Statistics on social work education in the United States: 1974. New York, NY: Author.

Council on Social Work Education. (1976). Statistics on social work education in the United States: 1976. New York, NY: Author.

Council on Social Work Education. (2012). 2012 Statistics on social work education in the United States. Alexandria, VA: Author. Retrieved from http://www.cswe.org/CentersInitiatives/DataStatistics/ProgramData/68987.aspx.

Flexner, A. (1916). Is social work a profession? In Proceedings of the National Conference on Charities and Correction, 1915 (pp. 576-590). Chicago, IL: National Conference on Charities and Correction.

Greenwood, E. (1957). Attributes of a profession. Social Work, 2, 45-55.

Leighninger, L. (1980). The generalist-specialist debate in social work. Social Service Review, 54(1), 1-12.

Leighninger, L. (1984). Graduate and undergraduate social work education: Roots of conflict. The Journal of Education for Social Work, 20(3), 66-77.

Leighninger, L., \& Stuart, P. (1999). BPD is launched: A history of the Association of Baccalaureate Social Work Program Directors, Part I. The Journal of Baccalaureate Social Work, 4(2), 37-58. 
Schatz, M. S., Jenkins, L. E., \& Sheafor, B. W. (1990). Milford redefined: A model of initial and advanced generalist social work. Journal of Social Work Education, 26(3), 217-231.

Sheafor, B. W. (2001). Three decades of baccalaureate social work: A grade card on how the professionalization of baccalaureate social work has played out. The Journal of Baccalaureate Social Work 6(2), 25-43.

Sheafor, B. W., \& Horejsi, C. R. (2012). Techniques and guidelines for social work practice $\left(9^{\text {th }}\right.$ ed.). Boston, MA: Allyn and Bacon.

Sheafor, B. W., \& Landon, P. S. (1987). Generalist perspective. In A. Minahan (Editorin-Chief), Encyclopedia of Social Work (18 ${ }^{\text {th }}$ ed., pp. 660-669). Silver Spring, MD: National Association of Social Workers.

Sheafor, B. W., Morales, A. T., \& Scott, M. E. (2012). Social work: A profession of many faces $\left(12^{\text {th }}\right.$ ed.). Boston, MA: Allyn and Bacon. (See Chapters 3 and 4.)

Sheafor, B. W., \& Shank, B. W. (1986). Undergraduate social work education: A survivor in a changing profession. Austin, TX: University of Texas School of Social Work, Social Work Education Monograph Series, \#3.

Stuart, P., \& Leighninger, L. (2000). BPD matures: A history of the Association of Baccalaureate Social Work Program Directors, Part II. The Journal of Baccalaureate Social Work, 5(2), 127-143.

Stuart, P., Leighninger, L., \& Donahoe, J. N. (1993). Reviewing our past: A history of the Association of Baccalaureate Social Work Program Directors. Eau Clair, WI: Association of Baccalaureate Program Directors.

Teare, R. J., \& Sheafor, B. W. (1995). Practice-sensitive social work education: An empirical analysis of social work practice and practitioners. Alexandria, VA: Council on Social Work Education.

\section{Author note}

Address correspondence to: Bradford W. Sheafor, 1426 W. Mountain Avenue, Fort Collins, CO 80521, bradford.sheafor@colostate.edu

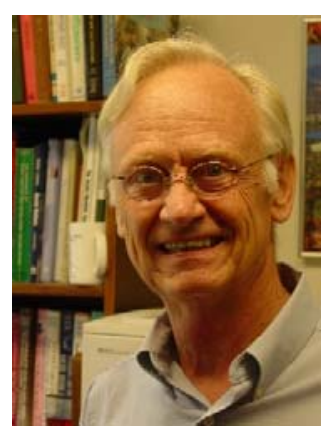

Brad Sheafor recently retired after 48 years as a social work educator at the University of Kansas and Colorado State University. A consummate generalist, Dr. Sheafor dabbled in many aspects of social work and social work education. His service activities included substantial involvement with NASW, ASWB, BPD, and CSWE. He also served as a Fulbright Lecturer in New Zealand and a visiting scholar in Australia. Major publications included Social Work: A Profession of Many Faces (12 editions), Techniques and Guidelines for Social Work Practice (10 editions), Practice-Sensitive Social Work Education, Quality Field Instruction in Social Work, and Undergraduate Social Work Education: A Survivor in a Changing Profession. 